\title{
Urethral Inverted Papilloma
}

National Cancer Institute

\section{Source}

National Cancer Institute. Urethral Inverted Papilloma. NCI Thesaurus. Code C6173.

A neoplasm of the urethra in which the epithelial cells grow downward into the underlying supportive tissue. 